\title{
Effect of Household Vermicompost and Fertilizer on Soil Microbial Biomass Carbon, Biomass Phosphorus and Biomass Nitrogen in Incubation Experiment
}

\author{
Kumar Chiranjeeb $^{1 *}$, S. S. Prasad ${ }^{1}$, S. P Singh ${ }^{1}$, Vikram Bharati ${ }^{2}$ and Sankar Jha1 \\ ${ }^{1}$ Department of Soil Science, Dr. Rajendra Prasad Central Agricultural University, \\ Pusa, Samastipur-848125 \\ ${ }^{2}$ Department of Agronomy, Tirhut College of Agriculture, Dholi, Pusa, Samastipur-848125, \\ *Corresponding author
}

\section{A B S T R A C T}

Keywords

Incubation, microbial biomass, vermicompost, fertilizer

\section{Article Info}

\section{Accepted:}

08 January 2020

Available Online:

10 February 2020
The incubation experiment consisting of four levels of vermicompost $(0 \mathrm{t}$ $\left.\mathrm{ha}^{-1}, 1.25 \mathrm{tha}^{-1}, 2.5 \mathrm{tha}^{-1}, 3.7 \mathrm{t} \mathrm{ha}^{-1}\right)$ and three levels of fertilizer $(0 \%, 100$ $\%, 50 \% \mathrm{RDF}$ ) were taken for analyzing the effect on the microbial biomass carbon, biomass nitrogen and biomass phosphorus in calcareous sandy loam soil at four stages of incubation (3 factors of variations) over a period of one year during kharif, 2018 at Dr. RPCAU, Pusa. During incubation experiment, microbial biomass carbon (MBC), microbial biomass nitrogen, microbial biomass phosphorus elevated from $0^{\text {th }}$ DAI to $115^{\text {th }}$ DAI. The microbial biomass carbon, microbial biomass phosphorus and microbial biomass nitrogen increased $101.84 \%, 40.63 \%, 42.52 \%$ over control at $115^{\text {th }}$ DAI respectively.

\section{Introduction}

Waste management is now a current burning problem in the whole world. Daily large metric tons of wastes are generated in world. The annual production of 700 million tons of organic waste produced in India is either burned or land filled (Bhiday 1994). The wastes include household wastes, agricultural wastes, industrial wastes and all these not only creates pollutions but also poor management cause deleterious effect on the soil environment altering soil physical, chemical and biological properties.

Vermicompost is the ultimate product of very finely divided, peat-like material with elevated porosity, showing excellent properties regarding drainage, good water holding capacity, high microbial activities for which it act as a good soil conditioner (Dominguez et al., 1997). Earthworm casts are known to contain enzymes such as 
proteases, lipases, cellulose, amylases and chitinase that continue to disintegrate the organic matter even after they have been excreted. Soil microbial biomass, which represents the living fraction of organic matter and act as a transformation matrix for the labile reservoir of nutrients like vaialble $\mathrm{N}, \mathrm{P}$ and $\mathrm{S}$ for the plants (Jenkinson and Ladd 1981: Singh et al., 1989). Soil microbial biomass carbon (MB-C) comprises $1-5 \%$ of total organic carbon (Zhang and Zhang, 2003; Nsabimana et al., 2004; Gil-Sotres et al., 2005). Because of its high turnover rate, MB$\mathrm{C}$ could respond more rapidly to changes of soil environment than soil organic matter (Powlson et al., 1987).

\section{Materials and Methods}

The present investigation was conducted at experimental station of Dr. RPCAU, Pusa, Samastipur in Kharif, 2018. In the incubation experiment the four levels of vermicompost (i.e. $0 \mathrm{t} \mathrm{ha}^{-1}, 1.25 \mathrm{t} \mathrm{ha}^{-1}, 2.50 \mathrm{t} \mathrm{ha}^{-1}, 3.75 \mathrm{t} \mathrm{ha}^{-1}$ ) and three levels of fertilizer (i.e. $0 \% \mathrm{RDF}, 50$ $\%$ RDF, $100 \%$ RDF) were mixed with $200 \mathrm{~g}$ of soil in incubation boxes and kept in the lab under controlled environment with proper moisture maintenance. The incubation experiment was carried out from 0 DAI (Days After Incubation) up to 115 DAI. The design of experiment was Factorial completely Randomized with three levels of factors (incubation days, vermicompost and fertilizer levels) along with twelve treatments and three replications.

\section{Microbial biomass carbon}

Microbial biomass carbon in soil and vermicompost was estimated following Chloroform fumigation extraction procedure as described by Jenkinson and Powlson (1976) and modified by Vance et al., (1987). Field sample (10 gm) was taken on oven dry basis, was fumigated with ethanol-free- chloroform for $24 \mathrm{hr}$ in a vacuum desiccators. Following evacuation and fumigant removal, the samples were extracted with $0.5 \mathrm{M} \mathrm{K}_{2} \mathrm{SO}_{4}$ (1:4 sample: solution ratio) by shaking for 30 minutes on an oscillating shaker. The sample suspension was filtered through Whatman No. 42 filter paper. Similarly, non-fumigated samples were also extracted with $0.5 \mathrm{M}$ $\mathrm{K}_{2} \mathrm{SO}_{4}$. The results were presented in terms of microbial biomass carbon $\mu \mathrm{g} \mathrm{g}_{-}{ }^{1}$ soil.

\section{Microbial biomass carbon in soil $\left(\mu \mathrm{g} \mathrm{g}^{-1}\right.$} soil)

$$
\begin{gathered}
\mathrm{SMBC}=\left(\underline{\text { Ext } \left._{\underline{\underline{f}}}-\mathrm{C}_{\underline{\mathrm{uf}}}\right)}\right. \\
\mathrm{K}_{\mathrm{EC}}
\end{gathered}
$$

Where,

Ext $\mathrm{C}_{\mathrm{f}}=$ extractable carbon in fumigated sample

$\mathrm{C}_{\mathrm{uf}}=$ extractable carbon in unfumigated sample

$\mathrm{K}_{\mathrm{EC}}=$ efficiency factor, which is 0.45

\section{Microbial biomass phosphorus}

$2.5 \mathrm{~g}$ of moist and dry soil was taken in container. One set of $10 \mathrm{~g}$ moist soil was kept in hot air oven for moisture calculation. The moist soil was fumigated with ethanol free chloroform and kept in incubator for 24 hours. The dry soil was only kept in refrigerator. After 24 hour both fumigated and unfumigated soil samples were shaken 30 mins with $0.5 \mathrm{M} \mathrm{NaHCO}$ and same process was followed for absorbance reading in case of phosphorus at 660nm.(Brookes et.al,1982)

\section{Microbial biomass nitrogen}

Ten gram moist soil was fumigated with $20 \mathrm{ml}$ chloroform and kept in container for 24 hours. Two set of 10gram soil were taken, one set was kept in hot air oven for moisture calculation and another set of unfumigated 
sample was kept in refrigerator. After 24 hours both fumigated and unfumigated soil samples were shaken with $100 \mathrm{ml}$ of $2 \mathrm{M} \mathrm{KCl}$ for 1 hour. The final calculation was according to Brookes et.al, (1985.)

Microbial biomass nitrogen in soil $\left(\mu \mathrm{g} \mathrm{g}^{-1}\right.$ soil)

$\mathrm{SMBN}=\frac{\frac{\operatorname{ExtN}\left(\mathrm{NH}_{4}-\mathrm{N}+\mathrm{NO}_{\mathrm{g}}-\mathrm{N}\right)_{\mathrm{f}}-\mathrm{ExtN}\left(\mathrm{NH}_{4}-\mathrm{N}+\mathrm{NO}_{\mathrm{g}}-\mathrm{N}\right)_{\mathrm{uf}}}{\mathrm{K}_{\mathrm{n}}}}{\mathrm{n}}$

Where,

Ext $\mathrm{N}_{\mathrm{f}}=$ extractable nitrogen in fumigated sample

Ext $\mathrm{N}_{\mathrm{uf}}=$ extractable nitrogen in unfumigated sample

$\mathrm{NH}_{4}-\mathrm{N}=$ extractable ammonical nitrogen

$\mathrm{NO}_{3}-\mathrm{N}=$ extractable nitrate nitrogen

$\mathrm{Kn}=$ efficiency of extraction of microbial biomass nitrogen (0.50)

\section{Results and Discussion}

\section{Microbial biomass carbon $\left(\mu \mathrm{g} \mathrm{g}^{-1}\right)$}

The microbial biomass carbon content in the soil during the incubation period has been depicted in (fig. 1).The microbial biomass carbon increased significantly with increasing levels of vermicompost and fertilizers irrespective of different incubation periods. Irrespective of all incubation periods, the increasing levels or doses of vermicompost increased the mean microbial biomass carbon from 118.18 to $185.24 \mu \mathrm{g} \mathrm{g}^{-1}$ soil and along with fertilizers levels increased from 136.33 to $179.84 \mu \mathrm{g} \mathrm{g}^{-1}$ soil.

With highest vermicompost doses the mean microbial biomass carbon increased from 84.24 to $126.29 \mu \mathrm{g} \mathrm{g}^{-1}$ soil, 90.66 to 146.08 $\mu \mathrm{g} \mathrm{g} \mathrm{g}^{-1}$ soil, 121.71 to $228.78 \mu \mathrm{g} \mathrm{g}^{-1}$ soil and 148.12 to $139.82 \mu \mathrm{g} \mathrm{g} \mathrm{g}^{-1}$ soil along with fertilizers doses increased biomass carbon from 88.90 to $133.42 \mu \mathrm{g} \mathrm{g}^{-1}$ soil, 108.55 to
$148.16 \mu \mathrm{g} \mathrm{g}^{-1}$ soil , 163.71 to $212.25 \mu \mathrm{g} \mathrm{g}^{-1}$ soil and 148.19 to $225.55 \mu \mathrm{g} \mathrm{g}^{-1}$ soil at $0^{\text {th }}$, $30^{\text {th }}, 65^{\text {th }}$ and $115^{\text {th }}$ DAI, respectively.

However during the incubation period the microbial biomass carbon increased at a increasing rate till $65^{\text {th }}$ DAI and increased at a decreasing rate from $90^{\text {th }}$ DAI to $115^{\text {th }}$ DAI. The highest dose of vermicompost $\left(3.75 \mathrm{t} \mathrm{ha}^{-}\right.$ $\left.{ }^{1}\right)$ along with highest dose of fertilizer $(100 \%$ RDF) showed significant increase in the microbial biomass carbon, which was superior than other vermicompost + NPK treatments but significantly superior than sole doses of vermicompost, NPK and control.

All the interactions of incubation stages, vermicompost and fertilizer doses were found significant. Similar results were reported by Ramachandran (2013). The application of organics and NPK increased MBC, might be due to priming effect (Muhammad et al., 2019).

\section{Microbial biomass nitrogen $\left(\mu \mathrm{g} \mathrm{g}^{-1}\right)$}

The microbial biomass Nitrogen content in the soil during the incubation period has been given in the fig. no. 2. The microbial biomass nitrogen increased significantly with increasing levels of vermicompost and fertilizers irrespective of different incubation periods. Irrespective of all incubation periods, the increasing levels or doses of vermicompost increased the mean microbial biomass nitrogen from 34.21 to $42.92 \mu \mathrm{g} \mathrm{g}^{-1}$ soil and along with fertilizers levels increased from 35.34 to $42.79 \mu \mathrm{g} \mathrm{g}^{-1}$ soil.

With highest vermicompost doses the microbial biomass nitrogen increased from 25.02 to $33.73 \mu \mathrm{g} \mathrm{g}^{-1}$ soil, 33.49 to $42.21 \mu \mathrm{g}$ $\mathrm{g}^{-1}$ soil, 37.60 to $46.31 \mu \mathrm{g} \mathrm{g}^{-1}$ soil and 40.70 to $49.41 \mu \mathrm{g} \mathrm{g}^{-1}$ soil along with high fertilizers doses increased biomass nitrogen from 26.30 to $33.68 \mu \mathrm{g} \mathrm{g}^{-1}$ soil, 34.64 to $42.09 \mu \mathrm{g} \mathrm{g}^{-1}$ soil, 
38.68 to $46.15 \mu \mathrm{g} \mathrm{g}^{-1}$ soil and 41.73 to 49.23 $\mu \mathrm{g} \mathrm{g}{ }^{-1}$ soil at $0^{\text {th }}, 30^{\text {th }}, 65^{\text {th }}$ and $115^{\text {th }}$ DAI, respectively. However during the incubation period the microbial biomass nitrogen increased at a gradual rate in all incubation periods from $0^{\text {th }}$ DAI to $115^{\text {th }}$ DAI but rate of increase was slightly slower after $65^{\text {th }}$ DAI.

The highest dose of vermicompost (3.75 t ha $\left.{ }^{1}\right)$ along with highest dose of fertilizer $(100 \%$ RDF) showed significant increase in the microbial biomass nitrogen, which was superior than other vermicompost $+\mathrm{NPK}$ treatments but significantly superior than sole doses of vermicompost, NPK and control.

All the interactions of incubation stages, vermicompost and fertilizer doses were found significant. Similar results were reported by Katkar et al., (2011) and also by Manna et al., (2013).The increasing levels of vermicompost with fertilizer dose might have increased nutrient contents in soil thus increasing biomass and contributing high biomass nitrogen (Pradip et al., 2018).

\section{Microbial biomass phosphorus ( $\mu \mathrm{g} \mathrm{g}^{-1}$ )}

The microbial biomass phosphorus content in the soil during the incubation period has been depicted in fig. no. 3.The microbial biomass phosphorus increased significantly with increasing levels of vermicompost and fertilizers irrespective of different incubation periods. Irrespective of all incubation periods, the increasing levels or doses of vermicompost increased the microbial biomass phosphorus from 2.98 to $3.47 \mu \mathrm{g} \mathrm{g}^{-1}$ soil and along with fertilizers levels increased MBP from 3.06 to $3.49 \mu \mathrm{g} \mathrm{g}^{-1}$ soil. With highest vermicompost doses the mean $\mathrm{s}$ microbial biomass phosphorus increased from 1.16 to $1.40 \mu \mathrm{g} \mathrm{g}^{-1}$ soil , 2.6 to $2.93 \mu \mathrm{g} \mathrm{g}^{-1}$ soil , 2.89 to $3.26 \mu \mathrm{g} \mathrm{g}^{-1}$ soil and 5.25 to $6.27 \mu \mathrm{g} \mathrm{g}$ 1 soil along with high fertilizers doses increased biomass phosphorus from 1.20 to $1.41 \mu \mathrm{g} \mathrm{g}^{-1}$ soil, 2.65 to $2.82 \mu \mathrm{g} \mathrm{g}^{-1}$ soil , 2.93 to $3.29 \mu \mathrm{g} \mathrm{g}^{-1}$ soil and 5.46 to $6.30 \mu \mathrm{g} \mathrm{g}^{-1}$ soil at $0^{\text {th }}, 30^{\text {th }}, 65^{\text {th }}$ and $115^{\text {th }}$ DAI, respectively.

The highest dose of vermicompost (3.75 $\mathrm{t} \mathrm{ha}^{-}$ $\left.{ }^{1}\right)$ along with highest dose of fertilizer $(100 \%$ RDF) showed significant increase in the microbial biomass phosphorus, which was superior than other vermicompost + NPK treatments but significantly superior than sole doses of vermicompost, NPK and control. The increasing levels of vermicompost with fertilizer dose increased the microbial biomass phosphorus during all stages of incubation could be due to optimum supply of nutrients for microbial activity which in turn increased the microbial biomass Phosphorus. The integrated application of FYM and fertilizer significantly improved microbial biomass phosphorus might be due to more addition of organic matter and nutrient availability (Babu et al., 2017).

Table.1 Pearson correlation matrix $0^{\text {th }}$ DAI (days after incubation) between incubation parameters

\begin{tabular}{|l|l|l|l|}
\hline & MBC & MBN & MBP \\
\hline MBC & $\mathbf{1 . 0 0 0}$ & & \\
\hline MBN & $0.921^{* *}$ & $\mathbf{1 . 0 0 0}$ & \\
\hline MBP & $0.895^{* *}$ & $0.965^{* *}$ & $\mathbf{1 . 0 0 0}$ \\
\hline
\end{tabular}

(** Significant at $\mathrm{P}=0.01$ level, *Significant at $\mathrm{P}=0.05$ level)

The correlation coefficient (table-1) showed highly significant in between the parameters.
The highest and positive coefficient was found in between MBP and MBN. 
Table.2 Pearson correlation matrix $30^{\text {th }}$ DAI (days after incubation) between incubation parameters

\begin{tabular}{|l|l|l|l|}
\hline & MBC & MBN & MBP \\
\hline MBC & $\mathbf{1 . 0 0 0}$ & & \\
\hline MBN & $0.944^{* *}$ & $\mathbf{1 . 0 0 0}$ & \\
\hline MBP & $0.946^{* *}$ & $0.960^{* *}$ & $\mathbf{1 . 0 0 0}$ \\
\hline
\end{tabular}

(** Significant at $\mathrm{P}=0.01$ level, *Significant at $\mathrm{P}=0.05$ level)

The (table-2) correlation coefficient showed found in between MBP and MBN and highly significant in between the parameters. followed by MBP and MBC.

The highest and positive coefficient was

Table.3 Pearson correlation matrix $65^{\text {th }}$ DAI (days after incubation) between incubation parameters

\begin{tabular}{|l|l|l|l|}
\hline & MBC & MBN & MBP \\
\hline MBC & $\mathbf{1 . 0 0 0}$ & & \\
\hline MBN & $0.870^{* *}$ & $\mathbf{1 . 0 0 0}$ & \\
\hline MBP & $0.844^{* *}$ & $0.980^{* *}$ & $\mathbf{1 . 0 0 0}$ \\
\hline
\end{tabular}

(** Significant at $\mathrm{P}=0.01$ level, *Significant at $\mathrm{P}=0.05$ level)

The correlation coefficient (table-3) showed The highest and positive coefficient was highly significant in between the parameters. found in between MBP and MBN.

Table.4 Pearson correlation matrix $115^{\text {th }}$ DAI (days after incubation) between incubation parameters

\begin{tabular}{|l|l|l|l|}
\hline & MBC & MBN & MBP \\
\hline MBC & $\mathbf{1 . 0 0 0}$ & & \\
\hline MBN & $0.992^{* *}$ & $\mathbf{1 . 0 0 0}$ & \\
\hline MBP & $0.987^{* *}$ & $0.999^{* *}$ & $\mathbf{1 . 0 0 0}$ \\
\hline
\end{tabular}

(** Significant at $\mathrm{P}=0.01$ level, *Significant at $\mathrm{P}=0.05$ level)

The correlation coefficient (table-4) showed The highest and positive coefficient was highly significant in between the parameters. found in between MBP and MBN. 
Int.J.Curr.Microbiol.App.Sci (2020) 9(2): 1508-1514

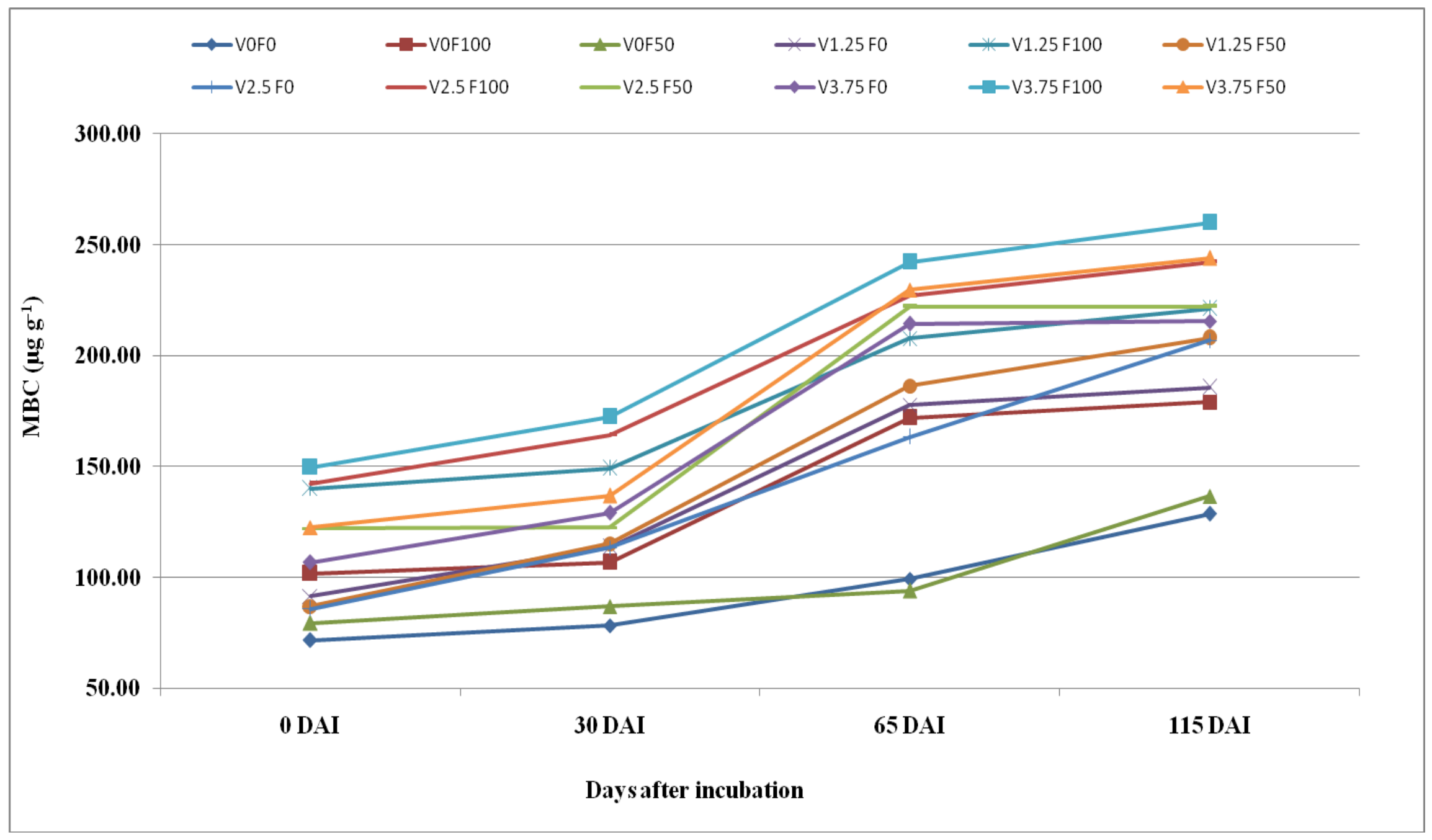

Fig.1 Effect of vermicompost and fertilizer on microbial biomass carbon -MBC $\left(\mu \mathrm{g} \mathrm{g}^{-1}\right)$ in soil during incubation study

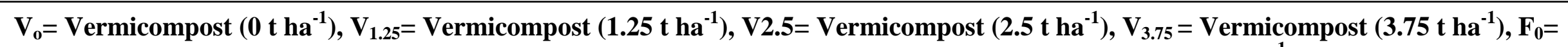
Fertilizer (no fertilizer), $\mathbf{F}_{100}=$ Fertilizer $(100 \%$ RDF $), F_{50}=$ Fertilizer $(50 \%$ RDF $)$ and $\mathbf{V}_{0} \mathbf{F}_{0}=$ control $\left(0 \mathrm{t} \mathrm{ha}^{-1}\right.$ vermicompost + no fertilizer ). 


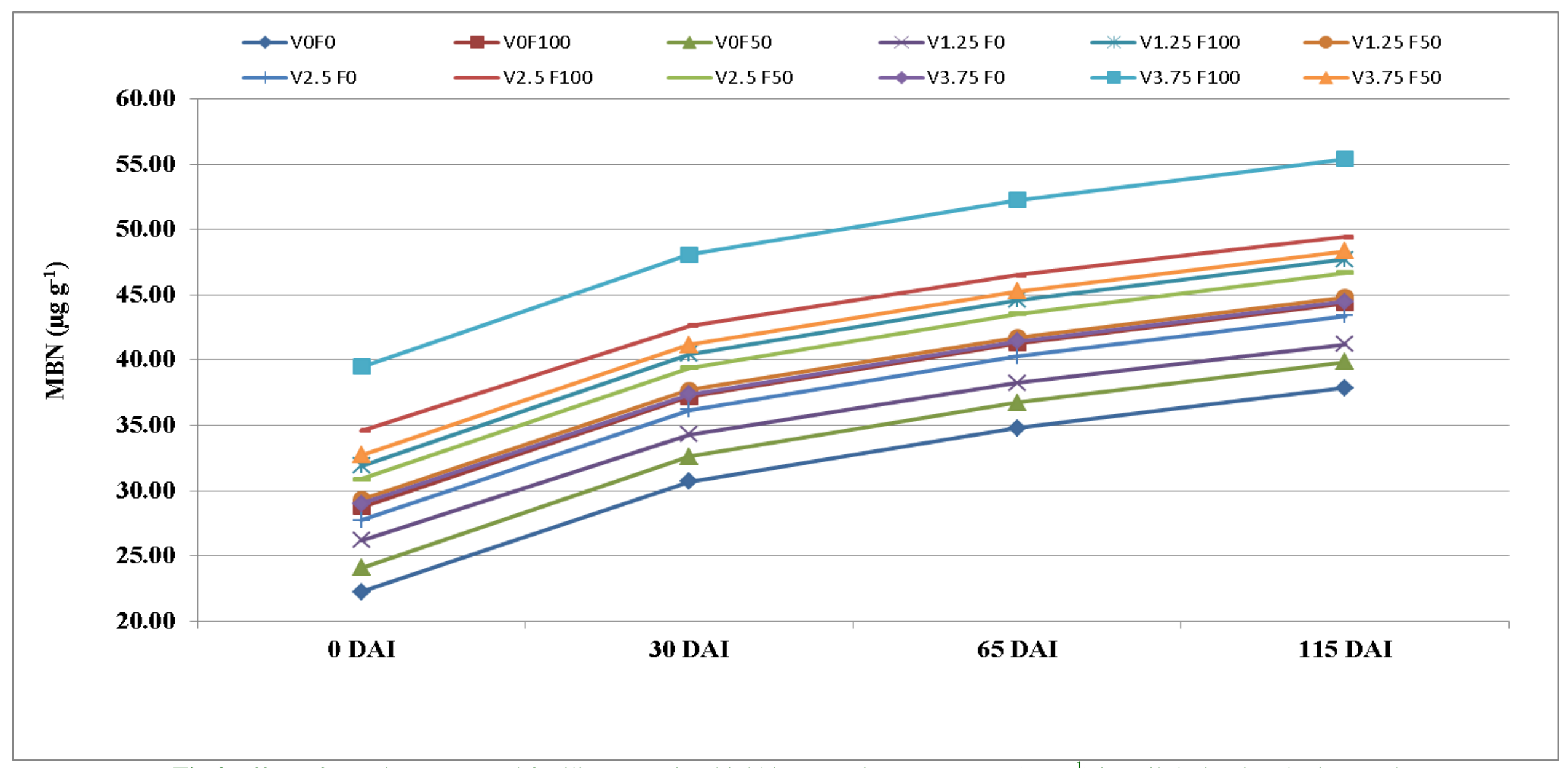

Fig.2 Effect of vermicompost and fertilizer on microbial biomass nitrogen -MBN $\left(\mu \mathrm{g} \mathrm{g}^{-1}\right)$ in soil during incubation study

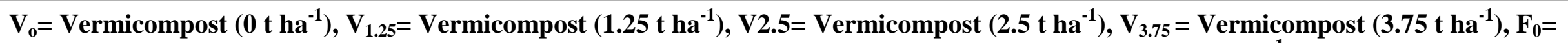
Fertilizer (no fertilizer),$F_{100}=$ Fertilizer $(100 \%$ RDF $), F_{50}=$ Fertilizer $(50 \%$ RDF $)$ and $V_{0} F_{0}=$ control $\left(0 t\right.$ ha ${ }^{-1}$ vermicompost + no fertilizer 
The study revealed that application of vermicompost and fertilizer together elevated the microbial biomass carbon, microbial biomass nitrogen and biomass phosphorus. The increase in organic matter content created complementary conditions for increasing the microbial population thus added more microbial biomass in soil under incubation study. The controlled conditions inside the incubation boxes favoured the increase in biomass. The combined application of vermicompost and fertilizer improved the soil health and soil ecological environments.

\section{Acknowledgement}

We would like to thank Department of soil science, Dr. Rajendra Prasad central Agricultural University for providing labs and equipments for smooth and east going of research.

\section{References}

1. Azeem, M., Hayat, R., Hussain, Q., Tahir, M.I., Imran, M., Sajid, M., Latif, A., Irfan, M. 2019. Effects of biochar and NPK on soil microbial biomass and enzyme activity during

2 years of application in the arid region. Arabian Journal of Geosciences. $12: 311$

2. Babu, A., Jatav, H.S., Verma, M. and Seema. 2017. Effect of FYM and Inorganic Fertilizer on Soil Microbial Biomass and Enzyme Activities of Indo Gangetic Plains, Varanasi, India International Journal of Current Microbiology and Applied Sciences. 6(2), 559-565.

3. Bhiday, M.R. 1994. Earthworms in Agriculture. Indian Farming. 43(12), 31 -34 .

4. Brookes, P.C., Kragt, J.F., Powlson, D.S. and Jenkinson, D.S. 1985. Chloroform fumigation and release of soil $\mathrm{N}$ : A rapid direct extraction method to measure biomass $\mathrm{N}$ in soil, Soil Biochemistry .17(6), 837-842.

5. Brookes, P.C., Powlson, D.S. and Jenkinson, D.S. 1982. Measurement of microbial biomass phosphorous in soils. Soil Biology and Biochemistry.14, 319321.

6. Domínguez, J., Edwards, C.A., and Subler, S. 1997b. A Comparison of vermicomposting and composting methods to process animal wastes. Biocycle. 38(4), 57-59.

7. Gil-Sotres F., Trasar-Cepeda M.C., Seoane S. 2005. Different approaches to evaluating soil quality using biochemical properties, Soil Biology and Biochemistry. 37: 877-887.

8. Jenkinson D.S., Ladd J.N. 1981. Microbial biomass in soil: measurement and turnover, in: Soil

Biochemistry, (Eds) Paul, E.A., and Ladd, J.N., Vol. 5, Marcel Dekker, New York.

9. Katkar, R.N., Sonune, B.A., and Kadu, P.R. 2011. Long-term effect of fertilization on soil chemical and biological characteristics and productivity under sorghum-wheat system in vertisol. Indian journal of Agriculture Science. 81(8), 734-739.

10. Nsabimana D., Haynes R.J., Wallis F.M. 2004. Size, activity and catabolic diversity of the soil microbial biomass as affected by land use. Applied Soil Ecology. 26: 81-92.

11. Powlson, D.S., Brookes, P.C. and Christensen, B.T. 1987. Measurement of soil microbial biomass provides an early indication of changes in total soil organic-matter due to straw incorporation. Soil Biology and Biochemistry. 19, 159-164

12. Ramachnadran, S., 2013. Influence of organic and mineral fertilization on organic carbon fractions, microbial 
properties and productivity of maizewheat cropping system on a typichaplustept. M.Sc. (Agri.) Thesis, Indian agricultural research institute, New Delhi.

13. Singh J.S., Raghubanshi A.S., Singh R.S., Srivastava S.C. 1989. Microbial biomass acts as a source of plant nutrient in dry tropical forest and savanna, Nature. 338: 499-500.

14. Tripura, P., Polara, K.B. and Shitab, M. 2018. Influence of Long Term Fertilization on Yield and Active Pools of Soil Organic Carbon in an
Typic Haplustepts under GroundnutWheat Cropping Sequence International Journal of Current Microbiology and Applied Sciences. 7(9): 781-794.

15. Vance, E.D., Brookes, P.C. and Jenkinson, D.S. 1987. An extraction method for measuring soil biomass carbon C. Soil Biology and Biochemistry.19 (6), 703-707.

16. Zhang H., Zhang G.L. 2003. Microbial biomass carbon and total organic carbon of soils as affected by rubber cultivation, Pedosphere. 13:353-357.

\section{How to cite this article:}

Kumar Chiranjeeb, S. S. Prasad, S. P Singh, Vikram Bharati and Sankar Jha. 2020. Effect of Household Vermicompost and Fertilizer on Soil Microbial Biomass Carbon, Biomass Phosphorus and Biomass Nitrogen in Incubation Experiment. Int.J.Curr.Microbiol.App.Sci. 9(02): 1508-1516. doi: https://doi.org/10.20546/ijcmas.2020.902.174 